\title{
Volatile compounds of Domiati cheese made from buffaloe's milk with different fat content
}

\author{
By Magda. A. Abd El-Mageed
}

Chemistry of Flavour and Aromatic Dept., N.R.C., Dokki, Cairo, Egypt

\section{RESUMEN}

Compuestos volátiles de queso Domiati fabricado de leche de búfalo con diferentes contenidos grasos.

La leche de búfalo fue procesada para obtener queso Domiati con diferente contenido graso en la cuajada ( $1 \%, 3.5 \%$ y $7 \%)$. Los resultados obtenidos durante el período de maduración revelaron que el queso con bajo contenido en grasa (Karish) no permite un largo período de almacenamiento, mientras que el queso con un contenido medio en grasa tuvo una buena calidad y flavor durante el período de maduración. El queso con alto contenido graso no duró más que el primer mes de maduración, deteriorándose posteriormente.

Los principales componentes encontrados fueron acroleína (propenal), heptanal, acetona, butan-2-ona, etanol, butan-2-ol, 2metil-propan-1-ol, 3 metil butan-1-ol, propionato de etilo, propionato de propilo, pentano y octano. Metil mercaptol, tiopropionato de metilo y trisulfuro de dimetilo junto con butirato de propilo se encontraron en muestras que fueron caracterizadas como muestras de quesos malos.

La mayoría de los compuestos anteriores se produjeron después de un mes de período de maduración.

PALABRAS-CLAVE: Compuestos volátiles - Leche de búfalo - Queso Domiati.

\section{SUMMARY}

Volatile compounds of Domiati cheese made from buffaloe's milk with different fat content.

Buffaloe's milk was manufactured to Domiati cheese with different fat content in the cheese milk (1\%, $3.5 \%$ and $7 \%)$. Results obtained during the ripening period revealed that the low fat cheese (Karish) is not able to long period storage, while half cream cheese had a good quality and flavour along the ripening period. The full cream cheese did not exceed the first month of ripening, then it deteriorated.

The main components found were acrolein (propenal), heptanal, acetone, butan-2 one, ethanol, butan-2 ol, 2-methylpropan-1-ol, 3-methyl butan-1-ol, ethyl propionate, propyl propionate, pentane and octane. Methyl mercaptan, methyl thiopropionate, and dimethyl trisulfide together with propyl butyrate, were existed in the samples which are characterized as bad cheese samples. Most of the previous compounds were developed after 1 month of ripening period.

KEY-WORDS: Buffaloe's milk - Domiati cheese - Volatile compounds.

\section{INTRODUCTION}

Domiati cheese is the most popular soft pickled cheese, not only in Egypt, but it is also widely consumed allover Arab World. Domiati cheese was first investigated in 1947 (1) followed by further studies in 1950 (2). The volatile compounds of Domiati cheese and of other types of cheese form (soft or hard) depends on numerous factors. Cow's milk showed faster rate of protein breakdown than that made from buffaloe's milk (3), fresh milk released more free fatty acids than those released from dried milk (4). The additives in the milk prior to manufacture and their effect on ripening acceleration were also studied, e.g. whey protein (5), trypsin hydrolysate (6) or free fatty acids (7). The addition of hydrogen peroxide gave a firm - bodied and typical flavoured cheese, but usually with a slight chemical aftertaste $(8,9)$. An increase in the fat content improved the cheese flavour but had an adverse effect on the body and texture (10).

Cotton seed oil, when added to cheese milk, led to a slight oily flavour $(11,12)$. Using highly autolyzed cheese slurry (Mish) to enhance the flavour of Domiati cheese made from recombined dried milk, showed acceleration in ripening, besides reducing its time and resulting cheese is characterized by good flavour within one month (13). The hydrolysis of fat and released fatty acids were more evident in Domiati cheese where milk was treated with either homogenization or lipase addition. The most remarkable variation in the cheese flavour was observed at the end of storage period (14). The addition of lipase enhanced the development of pickled soft cheese flavour after 30 days of storage (15). Domiati cheese made from skim milk or whole dried had the same pattern of free fatty acids when lipase preparation added (16). The volatile compounds isolated from fresh Feta cheese by the head space method contained relatively large quantities of ethanol, propan-1-ol, butan-2-ol and butan-2-one as well as smaller amounts of pentane, propan-2-ol, ethyl acetate, 2-methyl propan-1-ol, toluene and ethyl butyrate (17). In Domiati cheese it was investigated 
that within three months of ripening the volatile compounds were acrolein, propane-1-ol, butan-2-one, butan-2-ol in addition to large number of esters which appear during maturation. Moreover, various sulfur compounds contribute significantly to the overall cheese aroma. Most of the volatile compounds seemed to develop after 2-months of maturation (18), However the aim of this study was to investigate the role of fat in flavour development of pickled soft cheese.

\section{MATERIALS AND METHODS}

\section{Samples}

Buffaloe's milk $(20 \mathrm{~kg})$ was divided into three parts and standardized to contain fat as follows:

The first $1 \%$ fat (Karish, low fat),

The second $3.5 \%$ fat (half cream),

The third $7 \%$ fat (full cream).

The three parts of milk were manufactured separately to Domiati cheese samples by the traditional method (1).

Each of the produced samples was canned with its whey (6\% salt) and stored at room temperature. The samples were analysed for the volatile compounds and sensory evaluation after one week (fresh), 1 month, 2 months, and three months.

The analysed samples composition were as follow:

- Karish, Low fat: $10 \%$ fat / dry matter, $70 \%$ moisture and $\mathrm{pH} 6.03$.

- Half cream cheese: $20 \%$ fat / dry matter, $65 \%$ moisture and $\mathrm{pH} 6.4$.

- Full cream cheese: $45 \%$ fat / dry matter, $60 \%$ moisture and $\mathrm{pH} 6.51$.

\section{Organoleptic scoring of cheese}

The cheese was scored for

$\begin{array}{ll}\text { 1-Flavour } & 50 \text { points } \\ \text { Typical } & 30 \text { points } \\ \text { Bitterness } & 10 \text { points } \\ \text { Abnormal taste } & 10 \text { points } \\ \text { 2-Body \& Texture } & 40 \text { points } \\ \text { 3-Colour } & 10 \text { points }\end{array}$

by a regular score pannels from the scientific staff of Department of Food Technology \& Dairing, National Research Centre (19).

\section{Isolation of volatile components}

The volatile components of the cheese samples were extracted by simultaneous distillation method (20). About $200 \mathrm{~g}$ of each sample were suspended in $500 \mathrm{ml}$ distilled water, then continuously extracted with
$200 \mathrm{ml}$ pentane-diethyl ether (1:1). The pentane/ether extracts were dried over anhydrous sodium sulfate and the solvents were removed on a $25 \times 1 \mathrm{~cm}$ VIGREUX distilation column. The concentrates were stored under nitrogen.

\section{Gas chromatography - mass spectrometric analysis}

A Varian $3400 \mathrm{GC}$ equipped with DB - wax capillary column (O. $32 \mathrm{~m} \mathrm{~m}$ i.d. $\times 30 \mathrm{~m}$ ) and coupled to a Finnigan - Mat 55 Q 7000 was used.

Analyses were carried out by using helium as carrier gas, flow rate $1.1 \mathrm{ml} / \mathrm{min}$. Column temperature was maintained initially at $50^{\circ} \mathrm{C}$ for $6 \mathrm{~min}$ and then programmed from 50 to $260^{\circ} \mathrm{C}$ at a rate of $6^{\circ} \mathrm{C} / \mathrm{min}$. The injection port temperature was $250^{\circ} \mathrm{C}$. The ionization voltage applied was $70 \mathrm{ev}$. Peaks were identified by comparison with data from the library of mass spectra, literature data and mass spectra retention times of authentic samples. Quantitative determination was carried out based on peak area integration. Authentic components were purchased from Aldrich and Sigma Co, s.

\section{RESULTS AND DISCUSSION}

Table I shows the volatile components obtained from the three different cheese samples (Karish, half and full cream). About 44 compounds belonging to six chemical groups, namely, aldehydes, ketones, alcohols, esters, sulfur compounds, and hydrocarbons were identified.

Table II shows the component groups of the investigated cheese samples. It is observed that aldehydes content in the karish cheese fluctuated throughout the ripening period. It started with $5.79 \%$ in fresh cheese and decreased to $1.63 \%$ after one month, while the second month revealed the maximum value of aldehydes reaching $12.56 \%$. The increment of aldehydes did not occur in the third month but, in contrary, decreased sharply to reach $3.70 \%$. However, the major aldehyde for the fresh sample was heptanal compared to acetaldehyde and propenal (acrolein) which reported significant values during the second and third month of ripening. Ketones on the other hand started with a value of $5.15 \%$, then increased to $11.51 \%$ and $14.76 \%$ in the first and the second month of ripening, respectively. Thereafter, the value decreased to $8.29 \%$ during the third month of ripening. However, the predominant ketone for the fresh karish cheese sample was heptan-2-one while the major ketone during the first and the second month of ripening was butan-2-one. In the third month of 
Table I

Volatile components identified during the ripening period for Domiati cheese with different fat content

\begin{tabular}{|c|c|c|c|c|c|c|c|c|c|c|c|c|c|c|}
\hline \multirow{3}{*}{\multicolumn{2}{|c|}{$\begin{array}{l}\text { Peak } t_{R} \\
\text { No }\end{array}$}} & \multicolumn{4}{|c|}{ Low fat } & \multicolumn{4}{|c|}{ Half cream } & \multicolumn{4}{|c|}{ Full cream } & \multirow{3}{*}{ Components } \\
\hline & & \multirow[b]{2}{*}{ Fresh } & \multirow[b]{2}{*}{1} & \multirow[b]{2}{*}{ II } & \multirow[b]{2}{*}{ III } & \multicolumn{7}{|c|}{ Ripening period / month } & \multirow[b]{2}{*}{ III } & \\
\hline & & & & & & Fresh & 1 & II & III & Fresh & I & $\|$ & & \\
\hline 1 & 4.6 & $1.23^{*}$ & 0.25 & 4.24 & 0.92 & 4.17 & 0.60 & 4.09 & 0.94 & 3.56 & 4.16 & 21.39 & 0.07 & Acetaldehyde \\
\hline 2 & 5.1 & -- & -- & -- & -- & -- & -- & -- & -- & -- & -- & - & 0.15 & Methyl mercaptan \\
\hline 3 & 6.3 & 2.42 & 0.07 & 1.16 & 0.03 & 18.57 & 0.94 & 1.27 & 1.14 & 5.21 & 0.94 & 3.14 & 0.28 & Ethanol \\
\hline 4 & 6.7 & -- & 0.06 & 4.05 & 2.32 & -- & 11.55 & 1.16 & 0.99 & -- & 5.72 & 6.11 & 1.81 & Acrolein (propenal) \\
\hline 5 & 7.1 & 0.63 & 0.09 & 1.05 & 7.50 & 8.88 & 0.35 & 1.96 & 1.91 & 4.63 & 0.27 & 1.59 & 0.62 & Acetone \\
\hline 6 & 7.9 & 6.05 & 0.15 & 0.61 & 10.06 & 2.12 & 0.31 & 1.01 & 0.74 & 0.97 & 0.22 & 1.52 & 0.23 & Pentan \\
\hline 7 & 8.2 & -- & 0.09 & 2.92 & 14.42 & 0.64 & 2.94 & 2.26 & 1.15 & 2.60 & 0.79 & 1.74 & 0.17 & Ethyl formate \\
\hline 8 & 8.4 & -- & -- & -- & -- & -- & -- & -- & -- & -- & -- & -- & -- & Dimethyl sulfide \\
\hline 9 & 10.3 & 0.17 & -- & -- & -- & 0.94 & -- & -- & -- & 1.06 & -- & -- & - & Iso butyraldehyde \\
\hline 10 & 11.2 & 1.43 & 4.34 & 12.51 & 2.20 & 13.1 & 5.82 & 2.56 & 2.96 & 8.76 & 0.69 & 0.97 & 1.06 & Propan-1-ol \\
\hline 11 & 12.3 & -- & 0.40 & 1.51 & -- & -- & -- & -- & -- & -- & -- & -- & -- & Diacetyl \\
\hline 12 & 12.7 & -- & 0.40 & -- & -- & - & -- & -- & -- & -- & -- & -- & -- & Butyraldehyde \\
\hline 13 & 13.5 & 0.87 & 11.02 & 8.35 & 0.20 & -- & 0.54 & 0.97 & 1.07 & 5.97 & 0.66 & 0.42 & 0.84 & Butan-2-one \\
\hline 14 & 15.1 & 0.20 & 2.19 & 1.63 & 2.18 & 2.87 & 3.67 & 1.93 & 1.39 & 3.55 & 11.13 & 0.77 & 1.108 & Butan-2-ol \\
\hline 15 & 16.0 & 0.35 & 7.26 & 11.02 & 2.18 & 1.57 & 1.04 & 1.34 & 1.90 & 2.24 & 0.46 & 0.46 & 0.22 & Ethyl acetate \\
\hline 16 & 16.2 & -- & 5.73 & -- & -- & -- & -- & -- & -. & -- & -- & -- & -- & Unknown \\
\hline 17 & 17.9 & 0.81 & 6.09 & 2.59 & 0.11 & 6.16 & 12.19 & 1.97 & 1.79 & 6.98 & 11.44 & 0.86 & 2.44 & 2-Methyl-propan-1-ol \\
\hline 18 & 19.7 & 0.19 & 0.92 & 0.77 & -- & - & - & $T$ & 2.90 & -- & -- & 0.44 & $\mathrm{~T}$ & 3-Methyl butyraldehyde \\
\hline 19 & 21.1 & -- & -- & -- & 0.20 & 1.77 & 0.94 & 0.61 & 0.63 & 5.34 & -- & 0.62 & 5.20 & 2-Methyl butyraldehyde \\
\hline 20 & 24.2 & 1.26 & -- & -- & 0.03 & 2.16 & 0.36 & 0.49 & 0.67 & 6.98 & -- & 0.65 & 1.11 & Pentan-2-one \\
\hline 21 & 24.6 & -- & -- & -- & -- & -- & -- & -- & 0.79 & -- & -- & - & -- & Pentan-2,3-dione \\
\hline 22 & 24.8 & -- & -- & -- & -- & -- & -- & -- & -- & -- & -- & -- & -- & Valeraldehyde \\
\hline 23 & 25.1 & -- & 1.05 & -- & -- & -- & 0.27 & 0.61 & -- & -- & 0.61 & 0.59 & 1.03 & Methyl thioacetate \\
\hline 24 & 27.1 & -- & 1.34 & -- & 0.01 & -- & 0.26 & 1.01 & 0.94 & -- & 0.75 & 0.65 & 1.43 & Pentan-2-ol \\
\hline 25 & 28.2 & -- & -- & -- & 0.06 & -- & -- & 0.63 & 0.41 & -- & 0.20 & -- & -- & Ethyl propionate \\
\hline 26 & 28.6 & 0.84 & 1.48 & 1.81 & 0.10 & 30.64 & 0.27 & 0.77 & 3.26 & 5.68 & 0.91 & 0.48 & 0.68 & Propyl acetate \\
\hline 27 & 30.7 & -- & -- & -- & 0.07 & -- & 0.17 & 0.71 & -- & -- & -- & -- & -- & Dimethyl disulfide \\
\hline 28 & 31.0 & 1.24 & 0.90 & 0.36 & 0.04 & 2.46 & 0.30 & 1.04 & 3.46 & 13.73 & 1.81 & 0.96 & 0.61 & 3-methyl butan-1-ol \\
\hline 29 & 31.8 & -- & -- & -- & $\mathrm{T}$ & -- & -- & -- & $\mathrm{T}$ & $\mathrm{T}$ & -- & -- & $\mathrm{T}$ & 2-Methyl butan-1-ol \\
\hline 30 & 34.1 & 3.81 & 0.40 & 0.36 & -- & 2.10 & 0.12 & 0.36 & 1.64 & 4.22 & 0.54 & 0.96 & 23.05 & Un known \\
\hline 31 & 34.3 & -- & -- & -- & $\mathrm{T}$ & -- & $\mathrm{T}$ & $\mathrm{T}$ & 3.56 & -- & -- & $\mathrm{T}$ & $T$ & Toluene \\
\hline 32 & 36.2 & -- & -- & -- & -- & -- & -- & -- & -- & -- & -- & -- & -- & Hexan-2-one \\
\hline 33 & 37.3 & -- & -- & $\mathrm{T}$ & $\mathrm{T}$ & -- & -- & -- & $\mathrm{T}$ & -. & -- & -- & 2.53 & Methyl thiopropionate \\
\hline 34 & 37.5 & -- & -- & -- & -- & -- & -- & -- & -- & -- & -- & -- & -- & Capraldehyde \\
\hline 35 & 38.6 & 9.54 & 40.68 & 15.20 & 0.64 & 0.67 & 1.40 & 6.86 & 5.70 & 5.74 & 27.42 & 2.79 & 11.34 & Ethyl butyrate \\
\hline 36 & 39.7 & 55.20 & -- & 4.10 & 0.45 & -- & 54.43 & 48.29 & 46.56 & 12.68 & 28.91 & 10.33 & 15.03 & Propyl propionate \\
\hline 37 & 39.8 & -- & -- & 2.25 & - & 1.08 & 0.23 & 1.45 & 1.29 & - & 0.27 & 1.18 & 0.79 & Octane \\
\hline 38 & 40.1 & -- & -- & - & -- & -- & -- & -- & -- & -- & -- & -- & - & Butyl acetate \\
\hline 39 & 45.4 & -- & 6.14 & 1.87 & 3.12 & -- & -- & 6.20 & 6.50 & -- & 0.69 & 1.93 & 0.88 & Methyl thiobutyrate \\
\hline 40 & 46.3 & 3.40 & 1.22 & -- & -- & -- & -- & 3.50 & -- & -- & 0.33 & 0.74 & -- & P-.m-xylene \\
\hline 41 & 47.0 & -- & 1.38 & 5.10 & -- & -- & -- & 0.99 & 2.17 & -- & 0.33 & 1.92 & 0.44 & Iso amyl acetate \\
\hline 42 & 48.0 & 3.26 & -- & 3.85 & 0.56 & -- & -- & -- & -- & -- & -- & 1.18 & 0.41 & Heptan-2-one \\
\hline 43 & 48.5 & 4.11 & -- & 3.50 & 0.26 & -- & -- & 1.07 & -- & -- & -- & 0.98 & 0.31 & Heptanal \\
\hline 44 & 48.8 & 2.89 & -- & -- & -- & -- & -- & -- & -- & -- & -- & 0.63 & 0.16 & o- xylene \\
\hline 45 & 49.2 & -- & 6.32 & 9.07 & 39.24 & -- & 1.190 & 4.74 & 3.93 & -- & 1.29 & 31.54 & 25.19 & Propyl butyrate \\
\hline 46 & 57.0 & -- & -- & -- & 12.97 & -- & -- & -- & 2.09 & -- & -- & 2.33 & 0.76 & Dimetyl trisulfide \\
\hline
\end{tabular}

* Values expressed as area percentages.

$T=$ trace.

- = not detected or not determined. 
ripening, acetone showed the highest value among the ketone compounds of karish cheese. Alcohols of karish cheese had the same trend of the ketone compounds. The alcohol compounds were $6.10 \%$ for the fresh cheese, then increased during the first and the second months of ripening. The lowest value for alcohols occured at the end of ripening period, being $4.57 \%$. However, ethanol revealed the highest value among the alcohols of the karish sample. On the other hand, propan-1-ol and butan-2-ol were the predominant alcoholes in the ripened karish cheese. The ester compounds in fresh karish cheese recorded $66.81 \%$ which is quite a high value. The level of esters fluctuated during the ripening period being $49.34 \%$ and $57,22 \%$ for the second and third months of ripening, respectively. Propyl propionate was the major ester in fresh karish cheese. During ripening, ethyl butyrate was the major ester in the first month, while ethyl butyrate and ethyl acetate showed higher levels during the second month with propyl butyrate being the highest level at the end of the ripening period. Since the karish cheese curd consists mainly of casein and low content of fat, the substrate applied throughout the ripening period was milk protein. Sulfur compounds were not detected in fresh karish cheese, while marked concentration of $7.19 \%$ appeared after one month followed by decrease during the second month and strong increase (16.16\%) at the end. Methyl thiobutyrate being responsible in fresh and one mouth samples, in addition, dimethyl trisulfide, and dimethyl disulfide were the sulfur compounds detected at the end of ripening period.

Table II

Volatile compounds groups and total score of sensory evaluation obtained

for three cheese samples during ripening period. (expressed as area percent)

\begin{tabular}{lcccc}
\hline \multicolumn{5}{c}{ Low fat (Karish) cheese } \\
\hline & \multicolumn{5}{c}{ Low fat cheese } \\
\cline { 2 - 5 } Volatile groups & Fresh & I & II & III \\
\hline Aldehydes & 5.79 & 1.63 & 12.56 & 3.70 \\
Ketones & 5.15 & 11.51 & 14.76 & 8.29 \\
Alcohols & 6.10 & 14.93 & 18.25 & 4.57 \\
Esters & 66.81 & 58.00 & 49.34 & 57.22 \\
Sulfur compounds & 0 & 7.19 & 1.87 & 16.16 \\
Hydrocarbons & 12.34 & 1.37 & 2.86 & 10.06 \\
\hline Total organoleptic & 97 & 57 & 10 & 5 \\
test score (100) & & & & \\
\hline
\end{tabular}

\begin{tabular}{lrrrr} 
& \multicolumn{4}{c}{ Half cream cheese } \\
\cline { 2 - 5 } Volatile groups & Fresh & \multicolumn{1}{c}{ I } & \multicolumn{1}{c}{ II } & \multicolumn{1}{c}{ III } \\
\hline Aldehydes & 6.88 & 13.09 & 6.93 & 5.46 \\
Ketones & 11.04 & 1.25 & 3.42 & 3.65 \\
Alcohols & 40.29 & 23.18 & 9.78 & 11.68 \\
Esters & 36.49 & 61.38 & 66.03 & 63.39 \\
Sulfur compounds & 0 & 0.44 & 7.52 & 8.59 \\
Hydrocarbons & 3.20 & 0.54 & 5.96 & 5.59 \\
\hline Total organoleptic & 55 & 60 & 80 & \multicolumn{1}{c}{93} \\
test score (100) & & & & \\
\hline
\end{tabular}

\begin{tabular}{lcrrr}
\hline & \multicolumn{4}{c}{ Full cream cheese } \\
\cline { 2 - 5 } Volatile groups & Fresh & \multicolumn{1}{c}{ I } & \multicolumn{1}{c}{ II } & \multicolumn{1}{c}{ III } \\
\hline Aldehydes & 9.88 & 9.88 & 29.54 & 7.39 \\
Ketones & 17.58 & 0.93 & 3.84 & 2.98 \\
Alcohols & 38.23 & 26.77 & 7.83 & 6.92 \\
Esters & 29.14 & 60.45 & 48.91 & 53.13 \\
Sulfur compounds & 0 & 0.61 & 4.85 & 6.35 \\
Hydrocarbons & 0.97 & 0.82 & 4.07 & 1.18 \\
\hline Total organoleptic & 55 & 85 & 71 & 35 \\
test score (100) & & & & \\
\hline
\end{tabular}

Hydrocarbons are found in higher concentrations for fresh and three months ripening samples, while the lower concentrations were observed during the first and the second months. The hydrocarbon compounds were found to be pentane and o-xylene for the fresh sample. Low concentration $(0.15 \%)$ of pentane was detected in the second month of ripening. Pentane and octane were reported in the sample of two months ripening, while only pentane was detected in higher concentration during the third month. From the previous findings, it can be concluded that, inspite of the low fat content of the cheese, the ripening period led to a chemical or biological degradation of such low fat content, but the presence of the protein as a major substrate led to the higher concentration of the sulfur compounds due to such degradation $(21,22,15$ and 23).

Comparative data of the volatile compounds of fresh and ripened Domiati cheese considering the fat content of two samples revealed several differences not only in their concentrations, but also in the ripening time to obtain a good quality cheese.

Table II shows the volatile groups for the half and full cream cheese.

The concentration of the aldehyde compounds for the fresh half cream cheese were lower than those for fresh full cream cheese, $6.88 \%$ and $9.88 \%$, respectively. On the other hand, the trend of aldehydes decreased throughout the ripening period for the half cream cheese, while the full cream cheese sample had the highest level of aldehydes in the second month. Nevertheless, both samples contained the same 
aldehyde compounds, acetaldehyde, propenal, isobutyraldehyde, 3-methyl butyraldehyde, 2-methyl butyraldehyde, while the later is found in higher ratio in the full cream cheese sample, which might be derived from Strecker or microbiological degradation of amino acids (18).

Ketone compounds of fresh half cream cheese scored $11.04 \%$ among the other volatile compounds, leveling up to $17.58 \%$ for the full cream fresh cheese. Acetone and pentan-2-one were the ketones detected for the half cream cheese, however pentan-2-one was found in higher ratio for the full cream cheese. The high content of fat in the full cream cheese sample, might be the cause for the presence of butan-2-one due to beta oxidation of fatty acids (24).

The alcohol compounds (table II) were represented in both cheese samples as ethanol, propan-1-ol, butan-2-ol, 2-methylpropan-1-ol, and 3 methyl butan1-ol. The fresh half cream cheese sample had a higher ratio of ethanol and propan-1-ol than the fresh full cream cheese sample, while the reverse was observed for 3-methyl butan-1-ol. It is likely that these compounds could contribute to the differences in flavour between these two samples (17). Same alcohol compounds were found in both ripened cheese samples, but with variance in values. Butan-2-ol and 2methylpropan-1-ol were the major alcohols during the ripening period of the full cream cheese sample, while the 2-methylpropan-1-ol and propan-1-ol were the major aldehydes for the half cream cheese sample. Ethyl formate, ethyl acetate, propyl acetate, ethyl butyrate, propyl propionate were the esters detected for the full cream cheese. However, esters of fresh half cream recorded $36.49 \%$, compared to $29.14 \%$ for the full cream cheese sample. Propyl acetate and propyl propionate were the predominant esters detected for the fresh half and full cream cheese, respectively. Ester compounds of the fresh half cream cheese were significantly increased during the three months of ripening reaching their maximum in the second month. Among these esters, propyl propionate was the major ester detected throughout the ripening period as for the ester compounds of the full cream cheese they showed lower ratio than for the half cream samples. However, the full cream cheese had various esters in higher concentrations; ethyl, butyrate, propyl propionate and propyl butyrate beeing the major esters along the ripening period. The difference between the flavour of the half and full cream cheese samples might be due to the higher content of ethyl butyrate and propyl butyrate in the later samples. This finding is presumably attributable to the high content of fat in the full cream cheese samples, that may facilitate releasing short and medium chain fatty acids. However it has been reported that most of the esters arise from the fat hydrolysis $(21,25,26,27)$.

Various sulfur compounds such as methyl mercaptan, dimethyl disulfide, methyl thiopropionate, methyl thiobutyrate and dimethyl trisulfide were detected in different ratios. The fresh samples of the half and full cream cheese were clear of the sulfur compounds. Methyl mercaptan and methyl thiopropionate did not appear during the ripening period for the half cream cheese samples. Furthermore, dimethyl trisulfide was detected only at the end of the ripening period (third month), whereas methyl thiobutyrate existed significantly in the second and the third months, while dimethyl disulfide was detected in low percentages in the first and second months. Nevertheless, the samples of half cream cheese had a high score for its sensory evaluation.

Concerning the sulfur compounds existing in the samples of the full cream cheese, methyl mercaptan and methyl thiopropionate were reported only in the third month, while methyl thiobutyrate appeared from the first month to the end of ripening period. Dimethyl trisulfide existed through the second and the third months.

From the previous findings it is concluded that the methyl mercaptan and methyl thiopropionate were the sulfur compounds found in the full cream cheese sample in the third month, which could be the cause that the sample had the lower score in sensory evaluation and the off flavour detected in the cheese sample. Hydrocarbon compounds, mainly pentane and octane, were detected for the half cream cheese samples along the three months of ripening. Some other hydrocarbons existed frequently such as xylene isomers and toluene, when were detected during the second and the third months, respectively. On the other hand, all of the full cream cheese samples contained, pentane, octane, and xylene isomers were observed during the ripening period. However, pentane and octane, were probably produced through the oxidative breakdown of unsaturated fatty acids (28). From the previous discussions it is concluded that, the leakage of fat severely affected the flavour of the cheese during the ripening period so much that the flavour of the cheese becomes bad since the first month of ripening. The half cream cheese reached its maximum good flavour during the third month of ripening, which means that the fat content of half cream cheese was the optimum level for Domiati cheese ripening within three months. The increment of fat content in the cheese as presented in the full cream cheese sample did not give the promising results. The good quality of the full cream cheese did not cross the first month of ripening, when the flavour deterioration of the cheese existed since the second month of ripening.

So, the best time for consuming the Karish cheese, is in fresh state (the usual consumption time), while the best time for consuming the half cream cheese under the manufacturing conditions mentioned previously is accepted up to three month of ripening. The optimum consuming time for the stored full cream cheese is within the second month as maximum. 


\section{REFERENCES}

1. Sharara, H. A. (1947). -M. SC. Thesis, faculty of Agriculture, University of Cairo, Cairo, Egypt.

2. Fahmi, A.H., and Sharara, H. A. (1950). - «Studies on Egyptian Domiati cheese».- J. Agric. Res. 17, 312-328.

3. Rakshy, S.E.S.E. and Attia, I. (1979a). - «ldentification of amino acids liberated during ripening of cheese pickled in different salt concentrations».- Alexandria J. Agric Res. 27, 359-367.

4. Mehanna, N. M., El Shibiny, S. and Abd El-Salam, M. H. (1983). - «Proteolysis of soft cheese from recombined milk and made by ultrafiltration techniques".- Egyptian J. Dairy Sci. 11, 167-171.

5. Khorshid, M. A. and Rao, M. B. (1971). - «Studies on whey protein hydrolyzate II. Acceleration the ripening of Domiati cheese».- Milchwissenschaft 26, 472-474.

6. Nofal, A. A. and Abou - Dawood, A. E. (1975). -Research bulletin Faculty of Agriculture (K.E.S.), Tanta University, Citted from Abou - Donia, S. A. (1986) Review. «Egyptian Domiati soft white pickled cheese".- Newzealand J. of Dairy Sci. and Tecnol. 21, 167-190.

7. El-Safty, M. S. and Ismail, A. A. (1982). -«Addition of free fatty acids to improve the flavour and to accelerate the ripening of Domiati cheese made from reconstituted milk».- J. Dairy Res. 49, 671-675.

8. Sirry, I. and Kosikowski, F. V. (1959). -«Pasteurization and hydrogen peroxide treatments of milk for Egyptian Domiati Cheese».- XV International Dairy Congress. 2, 812-818. London.

9. Ghaleb, H. M. (1977). - «Contribution to loss in weight of Domiati cheese during pickling».- J. Agric. Res. Tanta University 3, 85-91.

10. Naghmoush, M. R., Abd El-Salam, M. H., Saleem, R. M. and El Abd, M. M. (1978). - «White pickled soft cheese from concentrated milk. I-Effect of fat content and addition of starter on the composition and quality of cheese".- Egypt. J. Dairy Sci. 6, 193-206.

11. El-Sokkary, A. M., El-Sadek, G. M. and Hamed, M. G. (1957). - «A study of the yield and pickling of Domiati cheese».- Annals of Agric. Sci (Cairo) 2, 123-137.

12. El-Shibiny. S., El-Koussy, L. A., Gergis, E. A. and Mehanna, N. (1983). - "The used of vegetable oils in making soft cheese from ultrafiltered recombined milk».Egypt. J. Dairy Sci. 11, 215-222.

13. Youness, N. A. (1991). - «Using of Mish as natural cheese flavour enhancer in Domiati cheese making".Egypt. J. Appl. Sci. 6, 279-286.

14. Youness, N. A., Abou-El-Naga, F.M. and Shahin, $Y$ (1990). - «Flavour of white soft cheese made from buffaloe's milk using different treatments of fat hydrolysis activation».- Agricultural Research Review 68, 707-713.

15. Abd El-Salam, M., El-Shibiny, S., Moneib, A., Aboul Heiba, A., El-Khamy, A. (1981). - "Addition of lipase in the manufacture of pickled soft cheese from whole milk and skim milk powder».- Egypt. J. Dairy Sci, 9, 143-149.

16. Omar, M. M., A. A. Abdel-Baky, A. M. Rabie. and M. M Ashour. (1986). - «Free Fatty Acids and quality Cheese Made From Dried Milks as Affected by an Added Lipase».- Egypt. J. Dairy Sci. 14, 225.

17. Horwood, J. F., Lioyd, G. T., and Stark, W. (1981). - Some Flavour components of feta cheese».- Aust. J. Dairy Technol. 36, 34-37.

18. Collin, S., Osman, M., Delcambre, S., El-Zayat, A.I. (1993). - «Investigation of volatile flavour compounds in fresh and ripened Domiati cheese».- J. Agric. Food Chem. 41, 1659-1663.

19. Nelson, J. A., and Trout, G.M. (1951). -«Judying dairy products».- 3rd ed. the Olsen pub-Co. Milwauke 12 Wis., p. 434.

20. Werkhoff, P., Bruning, J., Emberger, R., Guntert, M.; Kopsel, M. Kuhn, W. and Surburg, H. (1990). -Isolation and characterization of volatile sulfur-containing meat flavour components in model systems".- J. Agric. Food Chem. 38, 777-791.

21. El-Shibiny, S., Abd El-Baky, A. A., Farahat, S. M. Mahran, G. A. and Hofi, A. A. (1974). - «Development of free fatty acids in soft cheese".- Milchwissenschaft 29, 666-667.

22. Zein, G. N., Moussa, A. M., Mahmoud, S. A. Z. and Kamaly, K. M. (1979). - «The development of free amino and fatty acids in Domiati cheese during pickling".- J. Dairy Sci. 7, 183-190.

23. Shankaranarayana, M. L., Raghaven, B., Abraham, K. O., Natarajan, C. P. (1974). - «Volatile sulfur compounds in food flavours".- Crit. Rev. Food Technol. 4, 395-435.

24. Gallois, A. and Langlois, D. (1990). - «New results in the volatile odorous compounds of french cheese».- Lait 70 , 89-106.

25. El-Zayat, A. I. and Omer, M. M. (1987). -«Study on the ripening of white pickled brinza cheese made from ewe's milk».- Nahrung 31, 783-791.

26. Forss, D. A. (1979). -«Review of the progress of dairy science: Mechanisms of formation of aroma compounds in milk and milk products".- J. Dairy Res. 46, 691.

27. Forss, D. A. and Patton, S. (1966). - «Flavour of cheddar cheese".- J. Dairy Sci. 49, 89.

28. Grosch, W. (1982). - «Lipid degradation products and flavour». - In Food Flavours. Part A. Introduction; Morton, I. D., MacLeod, A. J., Eds., Elsevier: Amsterdam.

Recibido: Enero 1997 Aceptado: Octubre 1997 